\title{
The Relationship of Body Mass Index to Hemoglobin Levels
}

\author{
Yessy Aprihatin ${ }^{1 *}$, Devon $^{2}$, and Marisa Imral ${ }^{3}$ \\ ${ }^{1,2,3}$ Faculty of Sport Science, Universitas Negeri Padang, Padang, Indonesia \\ *Corresponding author. Email: yessyaprihatin@fik.unp.ac.id
}

\begin{abstract}
Study aims to identify the relationship between body composition and hemoglobin $(\mathrm{Hb})$ levels. The problem with some football players is that their hemoglobin levels are low. The method used in this research was Ex Post Facto. Selected research methods and experimental designs. The experimental design is presented in the form of a research star so that it can provide an idea for testing the effectiveness of a treatment. In this study, the sample interviewed were 16 football players. The results of this study are obtained from products that can detect the value of $t$ number $=0.389$ with a value of 0.0.703>0.05, which means that there is no true (large) number $\mathrm{X}$ number of the value of $\mathrm{t}$ body in the hemoglobin.
\end{abstract}

Keywords: Body Mass Index, Hemoglobin

\section{INTRODUCTION}

As it is known that hemoglobin is present in erythrocytes. This hemoglobin is a series of one protein molecule (globin) and four iron (heme). Each iron (heme) binds to one oxygen molecule, four oxygen molecules bound by hemoglobin. Oxygen molecules that have been bound to hemoglobin are then carried throughout the body's tissue cells for the oxidation process of food (glucose, fat and protein) so that it produces heat (heat) and energy.

The maximum amount of oxygen that can be transported by blood depends on the amount of hemoglobin present. Under normal circumstances there are about 15 grams in human blood and 16 grams of hemoglobin per 100 milliliters of blood in men, 14 grams of hemoglobin per 100 milliliters of blood in women. Each gram of hemoglobin can bind approximately 1.34 $\mathrm{ml}$ of oxygen. If the hemoglobin level is too high, also less favorable for circulation, because the level of blood viscosity (blood viscosity) is also high, so that it can inhibit the smooth circulation.

Thus the average hemoglobin in $100 \mathrm{ml}$ of blood can be combined with $20.1 \mathrm{ml}$ of oxygen (15 X 1.34).

The normal limit value of $\mathrm{Hb}$ levels according to the World Health Organization 2001 is for ages 5-11 years $<11.5 \mathrm{~g} / \mathrm{dL}, 12-14$ years $\mathrm{g} \leqslant 12.0 \mathrm{~g} / \mathrm{dL}$ over 15 years for females $>12.0 \mathrm{~g} / \mathrm{dL}$ and males $>13.0 \mathrm{~g} / \mathrm{dL}$.. $\mathrm{Hb}$ levels in the blood can be influenced by several factors, one of which is physical activity.

In those who increase hemoglobin sometimes. Because there is a greater need for tissue or cells $\mathrm{O} 2$ (oxygen) to perform their functions. (Bahri et al., 2009) in Mirza Juanda (2013). In doing soccer movements can increase physical activity, it means that exercise requires a lot of oxygen, where in the body producing oxygen which acts as a transport medium that delivers oxygen throughout the body is hemoglobin.

The normal limit of hemoglobin value for a person is difficult to determine because hemoglobin levels vary between each ethnic group. But WHO has set the limit of normal hemoglobin levels based on age and sex (WHO in Arisman, 2002).

Some factors that influence hemoglobin levels are : body mass index, age, food, sex, physical activity, lifestyle, genetics, and nutritional status.

The relationship between physical activity a person does on hemoglobin levels in a study that when a person performs physical movement, such as like fitness, there is an increase in metabolic activity, acids produced (hydrogen ions, lactic acid) more and more $\mathrm{pH}$ has decreased. A low $\mathrm{pH}$ will reduce the attraction between oxygen and hemoglobin. This will allow hemoglobin to release more oxygen and increase oxygen concentration in the muscles.

Another factor that influences hemoglobin levels is the Body Mass Index (BMI). BMI analysis is the result of calculating $\mathrm{BW}$ (body weight) and $\mathrm{H}$ (body height) by $\mathrm{BW} / \mathrm{H} 2(\mathrm{~kg} / \mathrm{m} 2)$. Based on time value, BMI was divided into three categories: weight (BMI, 418.4), mean $(B M I=18.525)$ and weight gain (BMI, 25.1).

Based on the above information, the purpose of the research is to uncover the relationship of Body Mass Index (BMI) with hemoglobin levels. 


\section{METHODS}

This study uses a large scale with a weighting model, to determine the relationship between body mass index (BMI) and hemoglobin levels. The sample size in this study was 16 soccer players over 14-20 years.

The instrument in this study was in the form of the Indonesian Physical Fitness Test. For the Hemoglobin Variable The test determining the hemoglobin level is Indonesian Physical Fitness for ages 14-20 years.

\section{RESULTS AND DISCUSSION}

\section{Coefficients $^{\mathrm{a}}$}

\begin{tabular}{|c|c|c|c|c|c|}
\hline & \multicolumn{2}{|c|}{$\begin{array}{c}\text { Unstandardi } \\
\text { zed } \\
\text { Coefficients }\end{array}$} & $\begin{array}{c}\text { Standardi } \\
\text { zed } \\
\text { Coefficie } \\
\text { nts }\end{array}$ & & \\
\cline { 2 - 4 } Model & B & $\begin{array}{c}\text { Std. } \\
\text { Error }\end{array}$ & Beta & T & Sig. \\
\hline $\begin{array}{c}1 \text { (Const } \\
\text { ant })\end{array}$ & $\begin{array}{c}13.46 \\
\text { IMT }\end{array}$ & 2.848 & & 4.726 & .000 \\
IMT & .053 & .137 & .103 & .389 & .703 \\
\hline
\end{tabular}

a. Dependent Variable: HB

In theory, the conceptual framework of this research is :

Variables included / subtracted ${ }^{\mathrm{b}}$

\begin{tabular}{|c|c|c|c|}
\hline Model & Variables Entered & $\begin{array}{c}\text { Variables } \\
\text { Removed }\end{array}$ & Method \\
\hline 1 & IMT $^{\text {a }}$ & & Enter \\
\hline
\end{tabular}

a. All requested variables entered.

b. Dependent Variable: HB

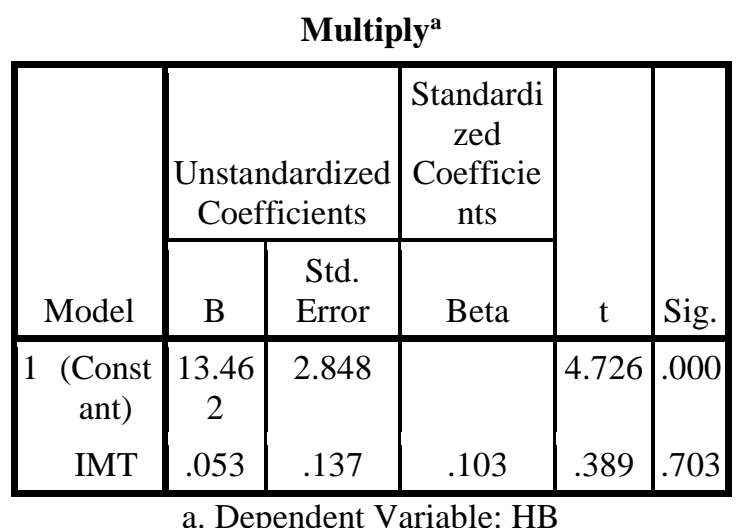

a. Dependent Variable: HB

\begin{tabular}{|c|c|c|c|c|c|}
\hline \multicolumn{6}{|c|}{ Multiply $^{\mathrm{a}}$} \\
\hline \multirow[b]{2}{*}{ Model } & \multicolumn{2}{|c|}{$\begin{array}{l}\text { Unstandardized } \\
\text { Coefficients }\end{array}$} & \multirow{2}{*}{\begin{tabular}{|c}
$\begin{array}{c}\text { Standardi } \\
\text { zed } \\
\text { Coefficie } \\
\text { nts }\end{array}$ \\
\\
Beta
\end{tabular}} & \multirow[b]{2}{*}{$\mathrm{t}$} & \multirow[b]{2}{*}{ Sig. } \\
\hline & B & $\begin{array}{l}\text { Std. } \\
\text { Error }\end{array}$ & & & \\
\hline $\begin{array}{c}1 \text { (Const } \\
\text { ant) }\end{array}$ & $\begin{array}{c}13.46 \\
2\end{array}$ & 2.848 & & 4.726 & .000 \\
\hline IMT & .053 & .137 & .103 & .389 & .703 \\
\hline
\end{tabular}

$\operatorname{ANOVA}^{b}$

\begin{tabular}{|c|c|c|c|c|c|}
\hline Model & $\begin{array}{c}\text { Sum of } \\
\text { Squares }\end{array}$ & df & $\begin{array}{c}\text { Mean } \\
\text { Square }\end{array}$ & $\mathrm{F}$ & Sig. \\
\hline $\begin{array}{c}1 \text { Regressi } \\
\text { on } \\
\text { Residua } \\
1\end{array}$ & .234 & 1 & .234 & .151 & $.703^{\mathrm{a}}$ \\
Total & 21.703 & 14 & 1.550 & & \\
\hline \multicolumn{5}{|c|}{ a. Predictors: (Constant), IMT } \\
\hline
\end{tabular}

b. Dependent Variable: HB

From the above output we can know the value of $\mathrm{t}$ arithmetic $=0.389$ with a significance value of $0.0 .703>0.05$, which means there is no real relationship (significance) variable $\mathrm{X}(\mathrm{BMI})$ to the participation variable (HB).

\section{CONCLUSION}

Based on these results it can be seen that the value of $\mathrm{t}$ arithmetic $=0.389$ with a significance value of $0.0 .703>0.05$, which means there is no significant effect (significance) variable $\mathrm{X}$ (BMI) on the participation variable (HB). There was no significant the link between body mass index (BMI) and hemoglobin levels in 16 soccer athletes.

\section{SUGGESTION}

As a result of these findings, there are many suggestions that researchers can make as follows:

1. Soccer player:

a. Should always pay attention to lifestyle and diet, so that their physical condition can be maintained properly.

b. In addition to maintaining good physical condition, lifestyle and eating patterns are also intended to maintain hemoglobin $(\mathrm{Hb})$ levels. Because Hemoglobin $(\mathrm{Hb})$ 
contained in the body is used to bind and transport Oxygen (O2) in the body.

2. The trainer, in addition to providing good training programs, physical and technical training also provides education to the user related to factors that can affect hemoglobin $(\mathrm{Hb})$ levels

\section{REFERENCES}

[1] Bafirman. (2008). Buku Ajar Kondisi Fisik. Padang: Fakultas Ilmu Keolahragaan Universitas Negeri Padang. Wineka Media.

[2] Umar. (2014). Fisiologi Olahraga. Padang. UNP Press Padang.

[3] Putra Rahmat Nurul Yuda, Ermawati, Ami Amir. (2016) Hubungan Indeks Massa Tubuh (IMT) dengan Usia Menarche pada Siswi SMP Negeri 1 Padang. (Jurnal Kesehatan Andalas), 2016. Volume 5, nomor 3.

[4] Gunadi Valerie I.R, Yanti M.Mewo, Murniati Tiho. (2016) Gambaran Kadar Hemoglobin pada Pekerja Bangunan. (Jurnal e-Biomedik (eBm)). Volume 4, nomor 2.

[5] Kosasi L, Oenzil F, Yanis A. Hubungan Aktivitas Fisik terhadap Kadar Hemoglobin pada Mahasiswa Anggota UMK pandekar Universitas Andalas. Jurnal Kesehatan Andalas. 2014;3(2).

[6] Halim EV, Ticoalu SHR, Wongkar D. Pengaruh Latihan Zumba terhadap Kadar Hemoglobin. Jurnal e-Biomedik. 2014;2(1).

[7] Bafirman. (2013). Fisiologi Olahraga. Cetakan 1Wineka media. Malang

[8] Ewangga B, Akbar IB, Nilapsari R. Perbedaan Kadar Hemoglobin yang berolahraga dan tidak Berolahraga. Bandung: Universitas Islam Bandung Repository. 2015. h. 172.

[9] Syafrizal dan Wilda Welis. 2009. Gizi Olahraga. Malang: Wineka Media.

[10] Ferry, M.William, Wilda Welis. (2019) Hubungan Kadar Hemoglobin Terhadap Kemampuan Vo2max Pada Pemain Sekolah Sepakbola (Ssb) Tunas Inti Kecamatan Sungai Bungkal Kota Sungai Penuh. (Jurnal Stamina), 2019, Volume 2, Nomor 1, 425436. 